\title{
Heterosis for Grain Yield and Component Traits in Quality Protein Maize
}

\author{
D. Singh ${ }^{*}$ and P. N. Jagadev \\ Department of Plant Breeding and Genetics, Odisha University of Agriculture and \\ Technology, Bhubaneswar, India \\ *Corresponding author
}

\section{A B S T R A C T}

\begin{tabular}{l} 
Key w or d s \\
Heterosis, \\
Heterobeltiosis, \\
Quality protein \\
maize, Zea mays \\
\hline Article Info \\
$\begin{array}{l}\text { Accepted: } \\
\text { 07 January } 2021 \\
\text { Available Online: } \\
\text { 10 February } 2021\end{array}$ \\
\hline
\end{tabular}

\section{Introduction}

Maize (Zea mays L.), the world's most widely grown cereal, occupies an important place in the food grain production scenario of Odisha. However, the productivity figure is very low due to the cultivation of landraces and composite varieties. Its nutritional qualities are superior to other cereals in most of the aspects. The maize kernel contains about 60-70 \% carbohydrates, 9-11\% crude protein, 2-3\% crude fibre, $3-5 \%$ lipids and $20 \mathrm{mg}$ of $\mathrm{Ca} / 100$ $\mathrm{g}$ of kernel. It also contains carotene, a precursor of vitamin A and a rich source of phosphorous with $348 \mathrm{mg} / 100 \mathrm{~g}$ of kernel (Wright, 1987). Maize is a highly cross pollinated crop and it has been successfully exploited for development of several hybrids and composites. However, most of the hybrids/composites developed were low in protein content. Breeding methods to improve yield along with increased protein level might develop quality protein in maize. The invention of heterosis phenomenon, the development of hybrid breeding technology and successful commercial exploitation of heterosis in maize are considered to be the significant achievements and landmarks in biological science. A number of genotypes like single cross, double cross, varietal hybrid, multiple hybrid, composite, synthetic etc., are feasible to the maize growing farmers for 
commercial cultivation by virtue of crop being highly cross pollinated. The efficiency and success of hybrid maize breeding depends on the contribution of heterotic effects from the superior inbred lines. The superior cross combination may be exploited as a commercial single cross. Usually, the hybrid development programme in maize involves the development and evaluation of inbred lines, crossing of selected inbreds and production of hybrids. Heterosis of varying degrees for grain yield and other component traits in maize have been reported (Amiruzzaman et al., 2010; Elmyhum et al., 2013 and Singh et al., 2013). Therefore, the present investigation was undertaken to assess the heterosis for grain yield and its components in a $5 \times 5$ diallel combination of quality protein maize genotypes to increase the production and productivity.

\section{Materials and Methods}

The experimental material comprised of five QPM inbreds (QPM 2-18, QPM 3-7, QPM 7 4, QPM 8-5, QPM 10-1) and 20 hybrids produced by $5 \times 5$ full diallel combination during the rabi season. Twenty hybrids produced from 5 x 5 full diallel combination and 5 parents were sown at EB-II Research Station of OUAT, Bhubaneswar following RBD with 3 replications in the following kharif season. Analysis of variance was carried out on mean values for all the 15 characters studied in $\mathrm{F}_{1}$ generation (Table 1). The source of variation due to genotypes (i.e. parents and hybrids) was further analyzed into sources like parents, hybrids and parents vs. hybrids. Significance of differences among parents, hybrids and between hybrids and parents as groups was tested by F-test. Relative heterosis ( $\mathrm{RH})$ was estimated as per cent increase (or decrease) of hybrid mean over the mid parent value for grain yield and its components. Heterosis over better parent i.e., heterobeltiosis (HB) was estimated as per cent increase of the hybrid from higher or lower parent mean (Turner, 1953). Heterosis was considered to be absent if the hybrid mean laid exactly at the mid-parental value of the two parents. The statistical significance of heterosic estimates was tested by t-test. The test was performed on the difference of the hybrid mean and the mid -parent value for $\mathrm{RH}$ and on the difference of the hybrid mean and higher or lower parent mean for $\mathrm{HB}$ before expressing them in percentage.

\section{Results and Discussion}

The mean squares of variation for parents, hybrids and parents vs. Hybrids revealed significant differences among the genotypes (Table 1). Variations due to parents vs. hybrids were significant for all the traits except days to $50 \%$ tasseling and silking and shelling $\%$ indicating presence of heterotic responses. The range of heterosis and number of crosses showing desirable heterotic responses for the characters over mid-parent (MP) as well as corresponding better parent (BP) were studied and the heterosis for grain yield ranged from -25.41 to $155.39 \%$ over MP (relative heterosis) and -0.01 to $148.62 \%$ over BP (heterobeltiosis) (Table 2). Out of 20 hybrids, all were having more number of grains per ear than MP, while only 18 were superior to their corresponding BP. For shelling \%, ear length and number of rows/ear, heterosis was exhibited by a few crosses. No cross showed BP heterosis for days to $50 \%$ silking.

For plant height, 10 hybrids each over MP and BP showed positive heterosis. Of the 7 hybrids having more number of rows/ear than MP, only 4 were superior to their corresponding BP. Heterosis for number of grains/ear was to the extent of $78.81 \%$ over MP and $69.25 \%$ over BP. For shelling \%, number of rows/ear, ear length and days to 50 $\%$ tasseling, heterosis was exhibited by a few crosses. 
Table.1 Analysis of variance of parents and hybrids for 15 characters in maize

\begin{tabular}{|c|c|c|c|c|c|c|c|c|c|c|c|c|c|c|c|c|}
\hline $\begin{array}{c}\text { Character/ } \\
\text { source }\end{array}$ & d.f. & $\begin{array}{c}\text { Days to } \\
50 \% \\
\text { tasseling }\end{array}$ & $\begin{array}{c}\text { Days to } \\
50 \% \\
\text { silking }\end{array}$ & $\begin{array}{c}\text { Days to } \\
75 \% \\
\text { dry } \\
\text { husk }\end{array}$ & $\begin{array}{c}\text { Plant } \\
\text { height } \\
(\mathrm{cm})\end{array}$ & $\begin{array}{c}\text { Ear } \\
\text { height } \\
(\mathbf{c m})\end{array}$ & $\begin{array}{c}\text { Ear } \\
\text { length } \\
(\mathrm{cm})\end{array}$ & $\begin{array}{l}\text { Ear } \\
\text { girth } \\
(\mathrm{cm})\end{array}$ & $\begin{array}{c}\text { No. of } \\
\text { rows/ } \\
\text { ear }\end{array}$ & $\begin{array}{c}\text { No. of } \\
\text { grains/ } \\
\text { row }\end{array}$ & $\begin{array}{l}\text { No. of } \\
\text { grains/ ear }\end{array}$ & $\begin{array}{c}\text { 100- } \\
\text { grain } \\
\text { weight } \\
\text { (g) }\end{array}$ & $\begin{array}{c}\text { Shelling } \\
(\%)\end{array}$ & $\begin{array}{c}\text { Harvest } \\
\text { index }\end{array}$ & $\begin{array}{c}\text { Ear } \\
\text { weight / } \\
\text { plant (g) }\end{array}$ & $\begin{array}{l}\text { Grain } \\
\text { yield } \\
(\mathbf{q} / \mathbf{h a})\end{array}$ \\
\hline Replication & 2 & 0.52 & 0.41 & 2.02 & $1660.29 * *$ & 52.59 & $32.79 * *$ & $2.59 *$ & $4.03 * *$ & $20.56^{*}$ & 656.04 & $9.61 * *$ & 2.31 & 0.77 & 11.06 & 6.68 \\
\hline Genotype & 24 & $6.25 * *$ & $6.32 * *$ & $23.18 * *$ & $633.45^{* *}$ & $141.49 * *$ & $9.45 * *$ & $1.53 *$ & $2.36^{* *}$ & $56.58^{* *}$ & $15031.46^{* *}$ & $29.26^{* *}$ & $2.48 * *$ & $528.58 * *$ & $2084.79 * *$ & $595.45^{* *}$ \\
\hline Parent & 4 & $18.10^{* *}$ & $15.10 * *$ & $37.40 * *$ & 151.63 & $93.48^{* * *}$ & $13.28 * *$ & 0.67 & 1.14 & $48.02 * *$ & $7710.14 * *$ & $33.10^{* *}$ & $1.66^{*}$ & $920.41 * *$ & $1598.97 * *$ & $382.37 * *$ \\
\hline Hybrid & 19 & $4.08 * *$ & $4.76^{* *}$ & $16.28^{* *}$ & $196.00^{*}$ & $81.44^{* *}$ & $6.11^{* *}$ & $1.04 *$ & $2.26^{* *}$ & $40.98 * *$ & $6038.53 * *$ & $181.16^{* *}$ & $2.63^{* *}$ & $457.72 * *$ & $1836.09^{* *}$ & $505.44 * *$ \\
\hline $\begin{array}{l}\text { Parent vs. } \\
\text { hybrid }\end{array}$ & 1 & 0.01 & 0.85 & $97.48 * *$ & $10872.14 * *$ & $1474.55^{* *}$ & $57.55^{* *}$ & $4.09 * *$ & $9.16 * *$ & $387.14 * *$ & $215182.60^{* * *}$ & $224.87 * *$ & 2.92 & $307.65^{* *}$ & $8753.27 * *$ & $3158.03 * *$ \\
\hline Error & 48 & 1.15 & 1.64 & 1.56 & 95.34 & 22.98 & 1.58 & 0.51 & 0.65 & 5.55 & 221.97 & 0.49 & 0.82 & 1.27 & 4.95 & 4.03 \\
\hline CVe (\%) & & 2.27 & 2.56 & 1.45 & 6.48 & 8.57 & 8.43 & 5.47 & 6.14 & 8.10 & 3.48 & 3.00 & 1.15 & 2.19 & 2.38 & 4.11 \\
\hline
\end{tabular}

$*$, ** Significant at $5 \%$ and $1 \%$ levels, respectively

Table.2 Range, significant crosses and best three hybrids for each trait based on significant heterotic responses over mid-parent (relative heterosis) and corresponding better parent (heterobeltiosis) for 15 morpho-economic traits in maize

\begin{tabular}{|c|c|c|c|c|c|c|c|}
\hline \multirow{2}{*}{$\begin{array}{l}\text { Sl. } \\
\text { No. }\end{array}$} & \multirow[t]{2}{*}{ Character } & \multicolumn{3}{|r|}{ Relative heterosis } & \multicolumn{3}{|r|}{ Heterobeltiosis } \\
\hline & & Range & $\begin{array}{l}\text { No. of } \\
\text { significant } \\
\text { crosses }\end{array}$ & Best three hybrids & Range & $\begin{array}{l}\text { No. of } \\
\text { significant } \\
\text { crosses }\end{array}$ & Best three hybrids \\
\hline 1 & $\begin{array}{l}\text { Days to } 50 \% \\
\text { tasseling }\end{array}$ & $\begin{array}{l}-4.70 \text { to } \\
7.75\end{array}$ & 4 & $\begin{array}{l}\text { QPM-8-5 x QPM 2-18, QPM 3-7 x QPM } \\
\text { 8-5, QPM 8-5 x QPM 3-7 }\end{array}$ & $\begin{array}{l}-4.05 \text { to } \\
5.04\end{array}$ & 1 & QPM 8-5 x QPM 3-7 \\
\hline 2 & $\begin{array}{l}\text { Days to } 50 \% \\
\text { silking }\end{array}$ & $\begin{array}{l}-5.01 \text { to } \\
6.21\end{array}$ & 2 & $\begin{array}{l}\text { QPM 8-5 x QPM 3-7, QPM 8-5 x QPM 2- } \\
18\end{array}$ & $\begin{array}{l}-4.49 \text { to } \\
3.35\end{array}$ & 0 & No significant cross \\
\hline 3 & $\begin{array}{l}\text { Days to } 75 \% \\
\text { dry husk }\end{array}$ & $\begin{array}{l}-1.20 \text { to } \\
8.64\end{array}$ & 14 & $\begin{array}{l}\text { QPM 8-5 x QPM 10-1, QPM 10-1 x QPM } \\
\text { 7-4, QPM 7-4 x QPM 8-5 }\end{array}$ & $\begin{array}{l}1.18 \text { to } \\
8.64\end{array}$ & 6 & $\begin{array}{l}\text { QPM 8-5 x QPM 10-1, QPM 10-1 x } \\
\text { QPM 7-4 QPM 7-4 x QPM 8-5 }\end{array}$ \\
\hline 4 & $\begin{array}{l}\text { Plant height } \\
(\mathrm{cm})\end{array}$ & $\begin{array}{l}17.63 \text { to } \\
36.74\end{array}$ & 10 & $\begin{array}{l}\text { QPM 8-5 x QPM 10-1, QPM 3-7 x QPM } \\
\text { 8-5, QPM 3-7 x QPM 7-4 }\end{array}$ & $\begin{array}{l}12.52 \text { to } \\
30.56\end{array}$ & 10 & $\begin{array}{l}\text { QPM 8-5 x QPM 10-1, QPM 3-7 x } \\
\text { QPM 7-4, QPM 3-7 x QPM 8-5 }\end{array}$ \\
\hline 5 & Ear height $(\mathrm{cm})$ & $\begin{array}{l}5.80 \text { to } \\
45.93\end{array}$ & 16 & $\begin{array}{l}\text { QPM 8-5 x QPM 10-1, QPM 8-5 x QPM } \\
\text { 2-18, QPM 8-5 x QPM 7-4 }\end{array}$ & $\begin{array}{l}2.04 \text { to } \\
36.13\end{array}$ & 10 & $\begin{array}{l}\text { QPM 8-5 x QPM 10-1, QPM 7-4 x } \\
\text { QPM 10-1, QPM 10-1 x QPM 3-7 }\end{array}$ \\
\hline 6 & Ear length $(\mathrm{cm})$ & 1.60 to & 6 & QPM 8-5 x QPM 10-1, QPM 7-4 x QPM & 6.01 to & 3 & QPM 8-5 x QPM 10-1 QPM 7-4 x \\
\hline
\end{tabular}




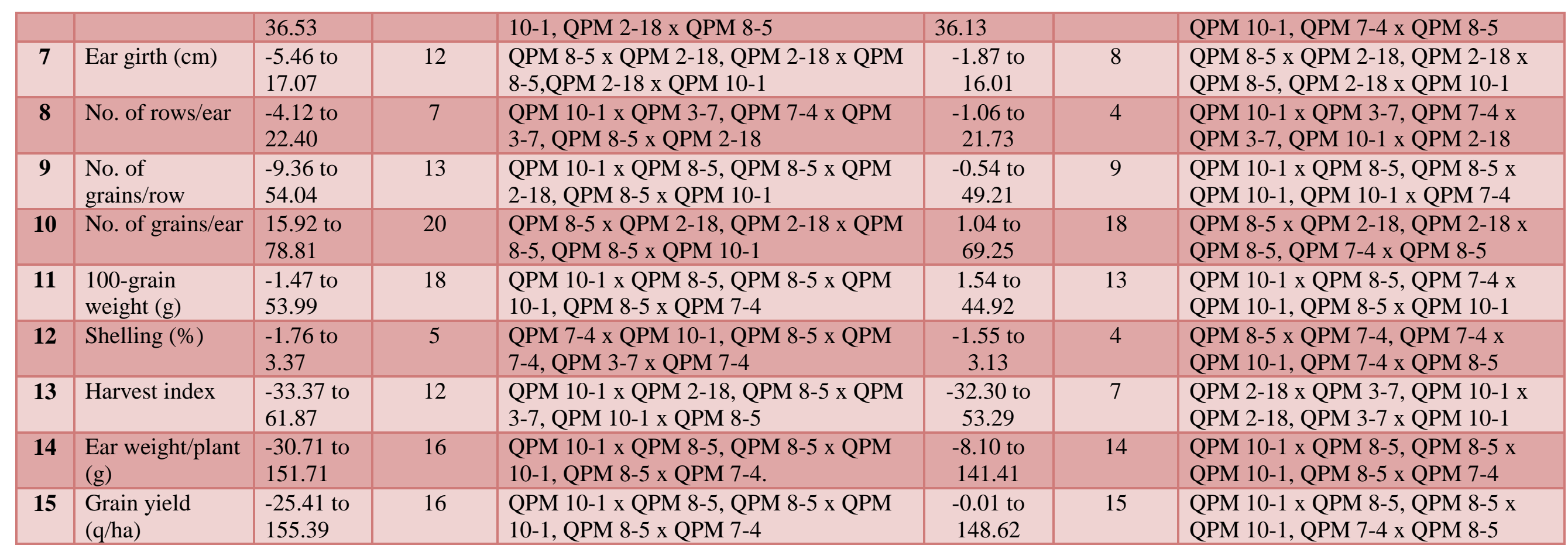

Table.3 Best five economic heterotic hybrids for grain yield over mid-parent (RH) and corresponding best parent (HB) and for other best five traits in maize

\begin{tabular}{|c|c|c|c|c|c|}
\hline \multirow{2}{*}{$\begin{array}{c}\text { Sl. } \\
\text { No. }\end{array}$} & Hybrid & \multirow{2}{*}{$\begin{array}{c}\text { Mean grain } \\
\text { yield (q/ha) }\end{array}$} & \multicolumn{2}{|c|}{ Heterosis (\%) } & $\begin{array}{c}\text { Significant heterosis } \\
\text { for other best 5 traits } \\
\text { (Sl. Nos.) \# }\end{array}$ \\
\hline $\mathbf{1}$ & & & & RB & \\
\hline $\mathbf{2}$ & QPM 10-1 x QPM 8-5 & 65.61 & $155.39^{*}$ & $148.62^{*}$ & $9,10,11,13,14$ \\
\hline $\mathbf{3}$ & QPM 8-5 x QPM 10-1 & 57.09 & $122.23^{*}$ & $116.33^{*}$ & $5,9,10,11,14$ \\
\hline $\mathbf{4}$ & QPM 8-5 x QPM 7-4 & 63.89 & $114.99^{*}$ & $93.35^{*}$ & $5,9,10,11,14$ \\
\hline $\mathbf{5}$ & QPM 8-5 x QPM 2-18 & 66.77 & $73.11^{*}$ & $31.56^{*}$ & $5,9,10,11,14$ \\
\hline
\end{tabular}

Best parent (QPM 2-18) mean yield $=50.75 \mathrm{q} / \mathrm{ha}$

* Significant at $5 \%$ level, RH = Relative heterosis, $\mathrm{HB}=$ Heterobeltiosis

\#Sl. Nos. for other traits correspond to the characters at Table 2 
Only four crosses each showed BP heterosis for number of rows/ear and shelling \%. Heterosis up to $22.40 \%$ over MP and 21.73 $\%$ over $\mathrm{BP}$ was recorded for number of rows/ear. Out of 20 hybrids, 15 had higher grain yield than their corresponding BP ranging the heterosis from -25.41 to $155.39 \%$ over MP and -0.01 to $148.62 \%$ over BP. The three best crosses selected for each trait based on significant heterotic response over MP and BP were presented in Table 2. The highest heterotic cross QPM 10-1 x QPM 8-5 was common in comparison for number of grains/row, 100-grain weight, harvest index, ear weight and grain yield.

Maximum heterosis was manifested in QPM 10-1 x QPM 8-5 for grain yield with high yield potential (Table 3). Cross of QPM 2-18 $\mathrm{X}$ QPM 8-5 with the highest per se performance showed $82.18 \%$ relative heterosis $(\mathrm{RH})$ with $38.45 \%$ heterobeltiosis (HB). In the reciprocal cross, QPM 8-5 x QPM 2-18 showed high heterosis coupled with high mean performance being the best parent QPM 2-18 yielded $50.75 \mathrm{q} / \mathrm{ha}$ of grains. The reciprocal cross QPM 8-5 x QPM $10-1$, the next highest heterotic cross was also common for days to $75 \%$ dry husk, plant height, ear height, ear length, number of grains, grain weight and grain yield. The findings were supported by Shalimuddin et al., (2006) and Kanagarasu et al., (2010). Hence, the cross QPM 10-1 X QPM 8-5 resulted as the best hybrid exhibiting very high mean grain yield $(65.61 \mathrm{q} / \mathrm{ha}$, an increase of $77.35 \%$ over the best parent QPM 2-18) with highest significant RH $(155.39 \%)$ and HB (148.62 \%) accompanied by significant heterosis for number of grains, grain weight, harvest index, ear weight and could be exploited for development of high yielding hybrids in quality protein maize.

\section{References}

Amiruzzaman, M. Islam, M.A. Hassan, L. and Rahman, M.M. 2010. Combining ability and heterosis for yield and component characters in maize. Acad. J. Plant Sci. 3(2): 79-84.

Elmyhum, M., Dessalegn, T. and Dessalegn, Y. 2013. Combining ability, gene action and heterosis estimation in quality protein maize. Intl. J. Sci. Res. Publn. 3(6): 1-17.

Kanagarasu, S., Nallathambi, G. and Ganesan, K.N. 2010. Combining ability analysis for yield and its component traits in maize (Zea mays L.). Electronic J. Pl. Breed. 4: 915-920.

Shalimuddin, M., Khatun, F., Ahmed, S., Ali, M.R. and Bagum, S.A. 2006. Heterosis and combining ability in corn ( Zea mays L. ). Bangladesh J. Bot. 35(2): 109-116.

Singh, P.K., Singh, N., Singh, A.K., Shahi, J.P. and Rao, M. 2013. Heterosis in relation to combining ability in quality protein maize (Zea mays L.). Biolife.1(2): 65-69.

Turner, J.K. 1953. A study of heterosis in upland Cotton-II, combining ability and inbreeding effects. Agron. J. 45: 487490.

Wright, A.J. 1987. The analysis and prediction of same two factor interactions in grass breeding. J. Agric. Sci.76 : 301-306.

\section{How to cite this article:}

Singh, D. and Jagadev, P. N. 2021. Heterosis for Grain Yield and Component Traits in Quality Protein Maize. Int.J.Curr.Microbiol.App.Sci. 10(02): 545-549.

doi: https://doi.org/10.20546/ijcmas.2021.1002.065 